\title{
Tsunami watch
}

\section{Five years after the Indian Ocean disaster, the technology is in place, but local preparedness is less advanced.}

On the morning of 29 September, Mase Akapo knew exactly what to do. At 6:48 a.m., on the island of Tutuila in American Samoa, he had felt the ground shake harder than he ever had before. Ten minutes later Akapo, a meteorologist, was in his office, issuing an alert for the tsunami he knew was probably on its way.

Tsunami warnings are a way of life for coastal communities, but five years ago they took on a new layer of meaning. On 26 December 2004, a magnitude-9.0 quake off the Indonesian island of Sumatra generated a series of tsunamis that drowned some 230,000 people around the Indian Ocean. Most of them had no idea it was coming.

Memory of the disaster remains relatively fresh in many coastal communities, even in the South

Pacific, where American Samoa and other nations have used it to brush up on their preparedness plans. "What we learned from that tsunami really helped us," says Akapo, whose 2009 warnings helped entire villages to reach safety before a massive wave struck Tutuila.

Experts say that much work remains, however. In all the world's major oceans although not the Mediterranean Sea, where some still see a risk - sophisticated tsunamisensing instruments are now on alert, from the extensive Pacific network first set up in 1965 to the brand-new system deployed across the Indian Ocean in the wake of the 2004 disaster (see graphic). Such systems rely on a network of seismic stations to detect the earthquake, and deep-ocean and coastal gauges to detect resulting changes in sea level. But the best instrumentation in the world cannot guarantee that crucial communication takes place where it is needed: at the waterfront, before the wave strikes, and in terms that local communities can understand and heed.

"In the Indian Ocean region there is a tremendous amount of work yet to be done," says Costas Synolakis, director of the University of Southern California's Tsunami Research Center in Los Angeles. "It is urgent work, because when it comes to tsunamis, bad information kills."

Before 2004, most people associated tsunamis with the Pacific Ocean, where the waves have repeatedly struck Japan and Hawaii. Few worried about such hazards in the Indian Ocean. Only $4 \%$ of all known tsunamis in the twentieth century occurred there - and none had struck in living memory in countries such as Thailand, India and Sri Lanka. Palaeorecords of ancient tsunamis suggest that the 2004 event was the biggest in that region in more than 600 years ${ }^{1,2}$.

At the time, the Indian Ocean had no tsunami warning system. By 2005, the Japan Meteorological Agency in Tokyo and the Pacific Tsunami Warning Center in Honolulu, Hawaii, had started issuing warnings as well as they could for the Indian Ocean with the instruments they had set up for the Pacific. And by the end of March 2010, the new Indian Ocean Tsunami Warning and Mitigation System will be fully operational. It includes 120 seismic stations, more than 60 coastal tide-gauge stations, 24 early-detection buoys and 20 deep-ocean 'tsunameters'.

The effort, which cost more than US $\$ 100$ million, is being paid for by various countries, with Germany, Indonesia and India assuming the largest shares. The 28 countries that are connected to the system are each responsible for collecting and feeding in their data to regional tsunami watch centres in Australia, India and Indonesia. If the data suggest a real threat, the centres will immediately send an alert back to national tsunami focal points, which in turn disseminate warnings to local communities and emergency services.

"People in the region are safer than they were in 2004," says Keith Alverson, project-office director with the Global Ocean Observing System of the United Nations Educational, Sci-

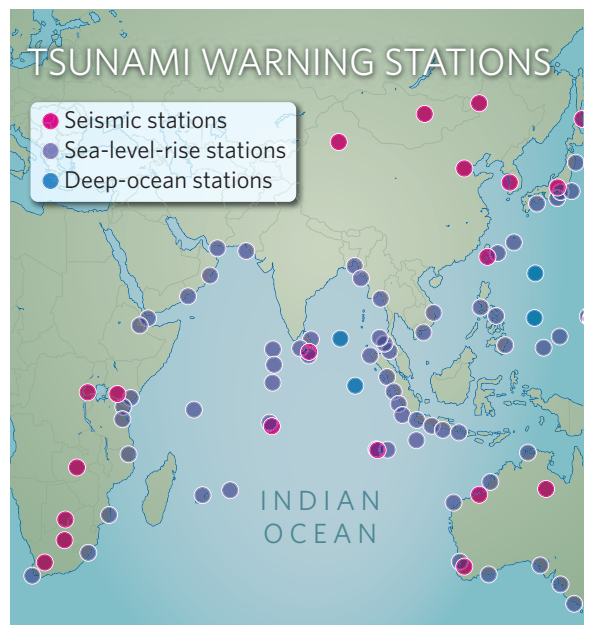

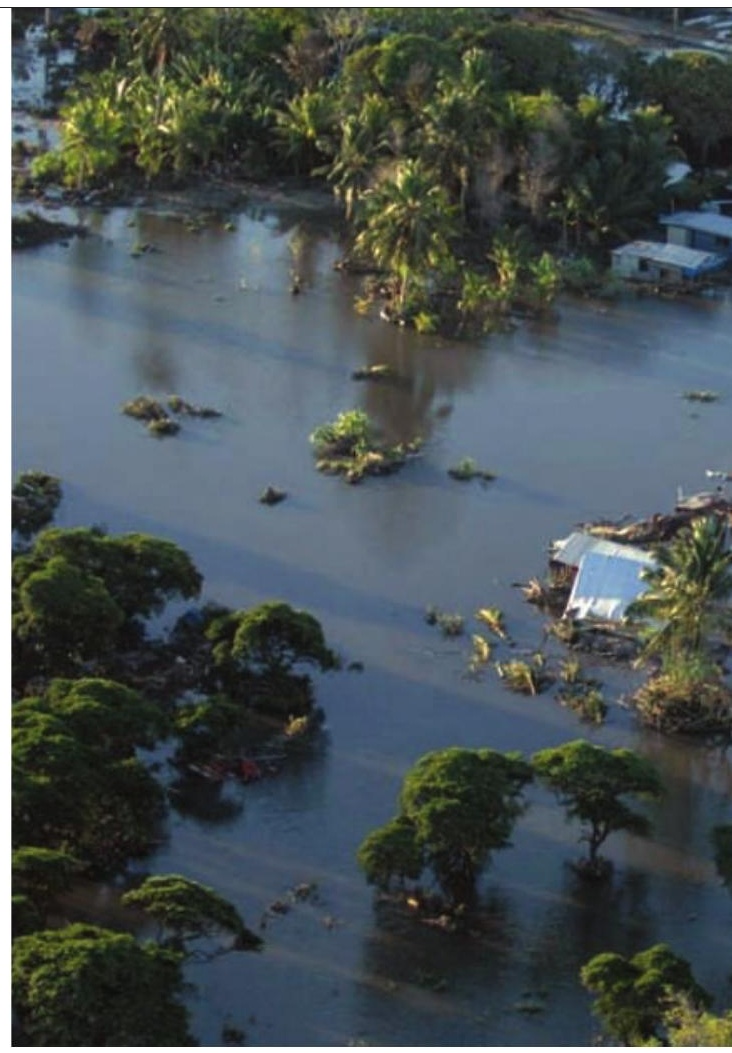

Early warnings saved lives in a 2009 tsunami in Samoa.

entific and Cultural Organization (UNESCO) in Paris. "The challenge is to tailor technology to local cultures and make the system sustainable in the long term," he says.

\section{Hidden dangers}

A tsunami that struck Java on 17 July 2006, killing more than 600 people, highlighted the limits of any warning system, no matter how technologically advanced. The tsunami arrived about 30 minutes after the earthquake, and survivors have reported that no warnings were issued. Lifeguards also failed to recognize the initial recession of water that typically precedes a tsunami, because it was masked by large, wind-driven waves breaking on the shore ${ }^{3}$.

The earthquake itself might have raised the alarm. "For people living close to a fault line, the only effective tsunami warning, alas, is the quake itself," says Harald Spahn, a geologist with the German Technical Cooperation who helps authorities in Sumatra, Java and Bali to improve tsunami warning capacities at the local level. But before the Java tsunami little or no ground-shaking was felt, which is typical for the 'slow' earthquakes that are common in the region.

Community-based public education and evacuation drills are essential to save lives in 


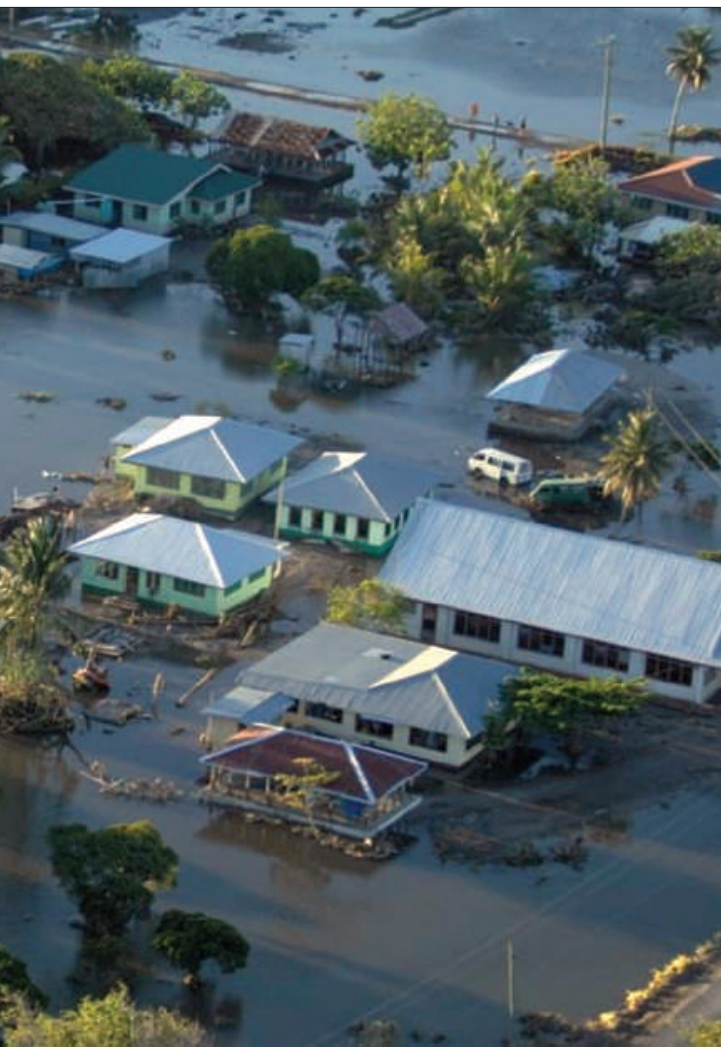

any tsunami, even if evacuation begins just minutes before the wave arrives. Regular drills are now conducted in some Javanese communities, but not all Indonesian coastlines are sufficiently prepared, says Spahn.

There have been some success stories in improving the communication of warnings down the critical 'last mile', he adds. For example, loudspeakers on mosques that normally call people for prayer are also an efficient way of broadcasting a tsunami warning, and have been used for this purpose in Sumatra and Java.

Similar public-education efforts paid off in saving lives in Samoa and American Samoa three months ago, says Bruce Jaffe, a coastalhazards researcher at the US Geological Survey in Santa Cruz, California. "Many people knew what to do," he says; they hurried on foot to higher ground.

The 2004 Indian Ocean tsunami, he says, provided "the wake-up call" to reinvigorate overall preparedness efforts for coastal communities around the world. But as more years pass since nearly a quarter of a million million people died, Jaffe worries that people's awareness will start to drop off again. "We can't let that happen," he says. "We've got to, if anything, step up the efforts."

Quirin Schiermeier, with additional reporting by Alexandra Witze

Jankaew, K. et al. Nature 455, 1228-1231 (2008)

2. Monecke, K. et al. Nature 455, 1232-1234 (2008).

3. Fritz, H. M. et al. Geophys. Res. Lett. 34, L12602 (2007).

I

ENCELADUS PLUME IS HALF ICE

Geysers not fed by misty water vapour after all. go.nature.com/Hpah3H

\section{Extortion attempt involved retracted papers}

Two papers retracted in the past few months have been linked to an extortion attempt. Both papers originated from the laboratory of Peter Schultz, a prominent chemist at the Scripps Research Institute in La Jolla, California.

Documents seen recently by Nature show that in 2007, law-enforcement officials in San Diego considered a former postdoctoral fellow from the Schultz lab as a possible suspect after another received an anonymous e-mail demanding a $\$ 4,000$ payment and threatening to reveal alleged fraud.

Law-enforcement officials did not pursue the case after the recipient of the e-mail decided not to press charges.

The retracted papers were published in Science ${ }^{1}$ and the Journal of the American Chemical Society $(J A C S)^{2}$. They claimed to describe the successful incorporation of amino acids linked to sugars at specific positions in proteins made by the bacterium Escherichia coli ${ }^{3}$.

On 1 March 2007, Zhiwen Zhang, the first author on the Science paper and the third author on the JACS paper, received an e-mail that read in part: "you have fraud on at least 3 papers and you stole library material- I found proof." The author of the e-mail asked Zhang to send cash to a post-office box in San Diego, and threatened that if Zhang did not comply, e-mails would be sent to Schultz, Scripps president Richard Lerner, and other scientists and administrators at Scripps and the University of Texas at Austin, where Zhang began working after he left the Schultz lab in 2004.

Zhang says he did not commit fraud. "I did no wrong, no scientific misconduct and no fraud," he says. "I am the victim of an extortion case, and I have suffered dearly."

The e-mail was forwarded to lawenforcement officials in San Diego. In March 2007, a southern California multiagency task force, the Computer and Technology Crime High-Tech Response Team, obtained warrants to search the records of Internet service providers in connection with the case. On 6 April, an officer with the task force notified Zhang that it considered Eric Tippmann, who overlapped with Zhang while both were postdoctoral fellows in Schultz's lab in 2004, to be a suspect. Zhang says that after consulting with Schultz and Lerner, he decided not to press criminal charges. Law-enforcement officials have confirmed that the investigation is closed.

Tippmann denies sending the extortion e-mail or contacting Zhang after Zhang left the Schultz lab. "If I was ever briefly mentioned in any investigation, I was never contacted nor interviewed, so this must have been a very short investigation," Tippmann wrote in an e-mail.

In August of this year, Tippmann and his colleagues published a study ${ }^{4}$ claiming that the experiments reported in the nowretracted papers could not have worked as described. Tippmann says he first became concerned about the papers in 2006 after he noticed what he alleges are similarities between mass spectra shown in the retracted JACS paper $^{2}$ and in an earlier JACS paper ${ }^{5}$ from the Schultz lab. Tippmann, now at Cardiff University, UK, says he also noticed other inconsistencies in some of the lab's papers, and flagged these to Schultz.

Zhang calls the issues raised by Tippmann "irrelevant". "It has all been cleared up," says Zhang, who says that Scripps has looked into the matter and cleared him of fraud and misconduct.

Schultz says that he has reproduced all of the results questioned by Tippmann, including other work that Zhang was involved in, except for the experiments that have now been retracted. He says that he is unsure why the mass spectra in the 2003 and 2004 JACS papers contain some similarities. "My guess is in that case a mistake was made," Schultz says. "I don’t think fraud was committed."

Zhang says that he stands by his original work.

Erika Check Hayden, with additional reporting by Rex Dalton

Zhang, Z. et al. Science 303, 371-373 (2004)

2. Xu, R. et al. J. Am. Chem. Soc. 126, 15654-15655 (2004)

3. Check Hayden, E. Nature 462, 707 (2009).

4. Antonczak, A. K., Simova, Z. \& Tippmann, E. M. J. Biol. Chem. 284, 28795-28800 (2009)

5. Alfonta, L., Zhang, Z., Uryu, S., Loo, J. A. \& Schultz, P. G. J. Am. Chem. Soc. 125, 14662-14663 (2003).

See go.nature.com/Innsou for a longer version of this story. 